\title{
A Variant of Leptin Gene Decreases the Risk of Gastric Cancer in Chinese Individuals: Evidence from a Case-Control Study
}

This article was published in the following Dove Press journal: Pharmacogenomics and Personalized Medicine

\section{Renjie Ma \\ Qi He}

Department of Infectious Disease, The People's Hospital of Danyang, Affiliated Danyang Hospital of Nantong University, Danyang, Jiangsu Province, 212300,

People's Republic of China
Correspondence: Qi He Tel/fax +86-5II-865530I5 Email heqi3214@I63.com
Background: A host of studies have explored the potential connection between leptin ( $L E P$ ) G19A polymorphism and the risk of cancers, but the relationship between gastric cancer (GC) susceptibility and LEP G19A polymorphism was not revealed before. The aim of this study was to investigate this relationship in Chinese Han population.

Methods: Thus, this case-control study with $380 \mathrm{GC}$ cases and 465 controls was designed to unearth the link between $L E P$ G19A polymorphism and GC susceptibility. Genotyping was accomplished by a custom-made 48-Plex SNP scanTM kit. Relative LEP gene expression was detected by real-time reverse transcription-polymerase chain reaction.

Results: LEP G19A polymorphism was shown to relate with a decreased risk of GC. Subgroup analyses uncovered significant connections in the males, nondrinkers, and those at age $<60$ years. G19A polymorphism was also linked with tumor size and location and pathological type of GC. Last, LEP gene expression in gastric tissues was considerably less than in control tissues.

Conclusion: This study shows that G19A polymorphism of $L E P$ gene is linked with a lower risk of $\mathrm{GC}$ in the tested Chinese Han individuals.

Keywords: $L E P$, gastric cancer, G19A polymorphism, case-control study

\section{Introduction}

Gastric cancer (GC) is the 3th dominant cause of cancer mortality and has the 5th highest incidence among cancers worldwide. ${ }^{1}$ The GC incidence and mortality rates are the highest in East Asia, and about 679,100 new GC patients and 498,000 cancer-associated deaths were reported in 2015 in China. ${ }^{2}$ GC has two anatomical types: gastro-oesophageal-junction adenocarcinoma and true gastric adenocarcinoma, ${ }^{3}$ and is histologically separated into diffuse and intestinal types. GC is a multi-step complex disorder due to both environmental and genetic factors. ${ }^{4}$ Tobacco smoking, alcohol consumption, Helicobacter pylori (HP) infection, and unhealthy dietary habits including low consumption of vegetables and fruits can induce the risk of GC. ${ }^{5-7}$ Genetic factors are also critical in GC progression. Genome-wide association research has recognized several gene polymorphisms are linked with the risk of GC. ${ }^{8-10}$

Leptin (LEP), a hormone of energy expenditure, is secreted by white adipose tissues and is associated with endocrinologic metabolism. ${ }^{11}$ It is expressed in the hypothalamus and regulates appetite and energy expenditure. ${ }^{12}$ LEP is engaged in energy homeostasis, insulin signaling, immune response, and inflammation. ${ }^{13-15}$ 
Reduced sensitivity to LEP may result in the development of metabolic disorders, such as cancers. ${ }^{16}$ LEP and its receptor are involved in various carcinogenesis-related signal pathways, including MAPK, PI3K, mTOR, and JAK/STAT. ${ }^{17,18}$ Increased LEP level is involved in the development of many malignancies. ${ }^{19-21}$ As for GC, LEP plays an important role in GC via stimulating the proliferation of GC cells through activating the ERK1/2 and STAT3 pathways. ${ }^{22}$ LEP can also enhance GC cell migration by increasing ICAM- $1{ }^{23}$ Recombinant human LEP could induce apoptosis and inhibit growth in human GC cell lines. ${ }^{24}$ Gastric LEP performed diverse functions including nutrient absorption and tumorigenesis in the gastrointestinal system. ${ }^{25}$ LEP could induce the expression of tumorigenic genes in the gastric mucosa of male rats. ${ }^{26}$ Dietary fat-accelerating LEP signaling was shown to promote protumorigenic gastric environment in mice. ${ }^{27}$ Overexpression of LEP was linked with the development of GC in humans and murine. ${ }^{25,28}$ Serum LEP levels were related with insulin resistance in GC patients ${ }^{29}$ and may be a valuable diagnostic indicator. ${ }^{30}$ LEP is connected with chemotherapy resistance and therapy-independent prognosis of GC. ${ }^{31}$ Besides, LEP was correlated with the progression and prognosis of GC patients. ${ }^{32}$

G19A polymorphism, a SNP in the 5'-untranslated region of $L E P$ gene, may impact RNA transcription, translation and steadiness, and change LEP protein expression. This polymorphism was correlated to cancer risk. ${ }^{33-45}$ However, the existing findings in different types of cancers are discrepant. Furthermore, no researchers have studied the relationship between G19A polymorphism and the risk of GC. To explore such potential relationships, we performed this study to explore this relationship in Chinese Han subjects.

\section{Patients and Methods}

\section{Subjects}

Totally 380 newly identified GC cases and 465 age- and gender-matched controls were enrolled from Danyang People's Hospital (Jiangsu, China) from March 2016 to January 2020. All GC patients received surgery treatment. $\mathrm{GC}$ tissues and normal tissues were obtained during surgery, which were stored at $-80^{\circ} \mathrm{C}$ after surgery. GC was diagnosed according to pathological examination results. Exclusion criteria for GC patients included: 1) a history of other cancers; 2) patients with gastritis; 3) patients with gastric ulcers; 4) patients not providing enough data and written informed consent. The age and gender-matched control individuals receiving health examinations were recruited from the hospital at the same period. Exclusion criteria for controls were as follows: patients 1) with a history of cancers; 2) with metabolic diseases; 3) with autoimmune diseases. 4) receiving no gastroscopy or having symptoms of gastritis. The demographic characteristics and lifestyle habits of all individuals were collected by a structured questionnaire. Medical records provided the clinical data of GC patients. All subjects completed a C-urea breath test to measure whether they had HP infection. The gastric tissues for RT_qPCR were not fresh because these tissues did not be used immediately after surgery. All individuals signed written informed consent in this study. Approval was obtained from the Ethics Committee of this Hospital (number: 20,200,618), and the Declaration of Helsinki was followed.

\section{Genotyping}

The blood samples of participants were stored at $-80^{\circ} \mathrm{C}$ immediately. DNA sample was from peripheral leukocytes using a TIANamp blood DNA kit (Qiagen, Hilden, Germany). LEP G19A polymorphism was genotyped using a custom-by-design 48-Plex SNP scanTM kit (Genesky Biotechnologies Inc., Shanghai, China). Each PCR system $(50 \mu \mathrm{L})$ contained $5 \mu \mathrm{L}$ of $10 \times$ PCR buffer for KOD-Plus-Neo, $1 \mu \mathrm{L}$ of upstream and downstream primers, $34 \mu \mathrm{L}$ of $\mathrm{ddH}_{2} \mathrm{O}, 1 \mu \mathrm{L}$ of temple, $2 \mathrm{mM}$ dNTPs $(5 \mu \mathrm{L}), 1 \mu \mathrm{L}$ of cDNA, $25 \mathrm{mM} \mathrm{MgSO} 4(3 \mu \mathrm{L})$, and $1 \mu \mathrm{L}$ of KOD-Plus-Neo (TOYOBO, Japan). Reaction conditions were $95{ }^{\circ} \mathrm{C}, 5 \mathrm{~min} ; 94{ }^{\circ} \mathrm{C}, 30 \mathrm{~s}, 50{ }^{\circ} \mathrm{C}, 30 \mathrm{~s} ; 72{ }^{\circ} \mathrm{C}, 1 \mathrm{~min}$, 35 cycles; extension at $72{ }^{\circ} \mathrm{C}, 10 \mathrm{~min}$, cooling to $4{ }^{\circ} \mathrm{C}$. The PCR products were digested with BglI (New England Biolabs, Beverly, MA) at $37^{\circ} \mathrm{C}$ for $5 \mathrm{~h}$ and then sent to $2 \%$ agarose gel electrophoresis. About $10 \%$ of the samples were repeatedly genotyped, and the concordance of genotypes was $100 \%$. ${ }^{46,47}$

\section{Reverse-Transcription Polymerase Chain Reaction (RT-PCR)}

The gastric tissues of participants were stored at $-80^{\circ} \mathrm{C}$. Total RNA was isolated from the gastric tissues from all subjects using the Trizol reagent (Invitrogen, CA, USA) and was reverse-transcribed with a relevant kit (TaKaRa, Shiga, Japan) as instructed by the manufacturers. The SYBR Green PCR master mix (TaKaRa, Otsu, Shiga, Japan) was used for real-time PCR. Forward and reverse 
primers used for PCR were: 5'-CGTTAAGGGAAG GAACTCTGG-3'， 5'-TTGATGGCTGAAGACCTTGG-3' (LEP); 5'-GATGAGATTGGCATGGCTTT-3', 5'-GTCAC CTTCACCGTTCCAGT-3' ( $\beta$-actin). The PCR condition was: an initial $94^{\circ} \mathrm{C}$ for $2 \mathrm{~min} ; 35$ cycles, $94^{\circ} \mathrm{C}, 30 \mathrm{~s}$, $60^{\circ} \mathrm{C}, 25 \mathrm{~s}$, and $72^{\circ} \mathrm{C}, 30 \mathrm{~s}$; final extension at $72^{\circ} \mathrm{C}, 10$ min. The relative expression of $L E P$ gene was calculated using the $2^{-\Delta \Delta \mathrm{CT}}$ method.

\section{Statistical Analysis}

Descriptive variables of GC patients and controls were shown as the mean and standard deviations for continuous variables, and frequencies and percentages for categorical variables. The Chi-square test was applied to compare the case-control differences in the distributions of genotypic frequencies and categorical variables. Student's $t$-test was adopted for continuous variables. The Hardy-Weinberg equilibrium (HWE) test was examined among the controls for LEP G19A polymorphism. The odds ratios (ORs) and 95\% confidence interval (CI) were computed via logistic regression. ${ }^{48}$ Five genetic models including dominant model, homozygote model, recessive model, heterozygote model, and allele model were utilized in this study. Stratified analyses by sex, age, smoking and alcohol were done. We addressed the association of LEP G19A polymorphism with clinical features of GC patients. $P<$ 0.05 was the significance level. All data analyses were finished on SPSS 22.0 (SPSS Inc., USA).

\section{Results}

\section{Population Characteristics}

A flowchart of patient enrollment is shown in Figure 1. Totally 380 GC patients and 465 controls were involved. Clinical data are listed in Table 1. Data showed no remarkable discrepancy between cases and controls in age, sex, alcohol, or smoking. The percentage of HP infection was higher in GC patients than the controls. Additionally, LEP gene level in gastric cancer tissues versus normal tissues was significantly lower (Figure 2).

\section{Association of LEP GI9A Polymorphism with GC Risk}

LEP G19A polymorphism was in line with $\operatorname{HWE}(P>$ 0.05). Data found that the AA genotype (OR: $0.50 ; 95 \%$ CI: $0.26-0.97 ; P=0.040$ ) or A allele (OR: $0.73 ; 95 \% \mathrm{CI}$ : $0.58-0.93 ; P=0.009)$ of G19A polymorphism showed a less risk for GC (Table 2). These associations hold true

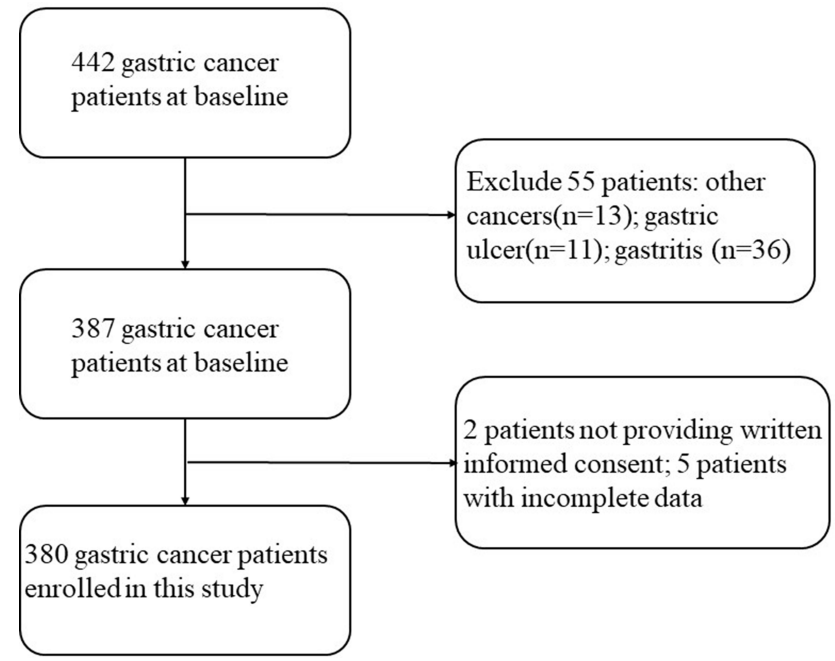

Figure I The flowchart of patient enrollment.

even after adjusting for age and sex. Stratified analyses demonstrated that this polymorphism was linked to a lower risk of GC patients among the non-drinkers, males, and those at age $<60$ years (Table 3 ). No significant associations were obtained in subgroup analysis of smoking and HP status.

\section{Relationship Between LEP GI9A Polymorphism and Clinical Features of GC}

Last, we addressed the relationship between G19A polymorphism of LEP gene and GC clinical features (Table 4). The SNP was related to tumor size, cardia GC and adenocarcinoma, but not to histological grade, $\mathrm{R}$ classification, or TNM stage.

\section{Discussion}

In this case-control study, we observed that $L E P$ G19A polymorphism was correlated with less risk for GC in Chinese subjects. Next, this polymorphism can lower the risk of GC patients among non-drinkers, males, and those at age $<60$ years. In addition, LEP G19A polymorphism showed connection with tumor size, cardia GC and adenocarcinoma. Last, $L E P$ gene level in gastric tissues was remarkably lower than in normal tissues.

Some recent case-control studies have probed into the possible relationship between $L E P$ G19A polymorphism and the risk of various cancers. Tsilidis et al observed no association between this locus and CRC susceptibility in a Caucasian population from the USA. ${ }^{33}$ Later, a study with 1567 cases and 1965 controls from the USA indicated 
Table I Patient Demographics and Risk Factors for Gastric Cancer

\begin{tabular}{|c|c|c|c|}
\hline Characteristics & $\begin{array}{l}\text { Case } \\
(\mathrm{N}=380)\end{array}$ & $\begin{array}{l}\text { Control } \\
(\mathrm{N}=465)\end{array}$ & $P$ \\
\hline Age & $\begin{array}{l}57.51 \\
(34-89)\end{array}$ & $\begin{array}{l}55.94 \\
(31-92)\end{array}$ & 0.064 \\
\hline $\begin{array}{l}\text { Sex } \\
\qquad \text { Male } \\
\text { Female }\end{array}$ & $\begin{array}{l}196(51.6 \%) \\
184(48.4 \%)\end{array}$ & $\begin{array}{l}242(51.6 \%) \\
223(48.4 \%)\end{array}$ & 0.893 \\
\hline $\begin{array}{l}\text { Smoking } \\
\text { Yes } \\
\text { No }\end{array}$ & $\begin{array}{l}|9|(50.3 \%) \\
\mid 89(49.7 \%)\end{array}$ & $\begin{array}{l}230(36.6 \%) \\
235(63.4 \%)\end{array}$ & 0.817 \\
\hline $\begin{array}{l}\text { Alcohol } \\
\text { Yes } \\
\text { No }\end{array}$ & $\begin{array}{l}213(56.1 \%) \\
167(43.9 \%)\end{array}$ & $\begin{array}{l}246(42.0 \%) \\
219((58.0 \%)\end{array}$ & 0.361 \\
\hline $\begin{array}{l}\text { H. pylori } \\
\text { Seronegative } \\
\text { Seropositive }\end{array}$ & $\begin{array}{l}68(17.9 \%) \\
312(82.1 \%)\end{array}$ & $\begin{array}{l}191(44.3 \%) \\
274(55.7 \%)\end{array}$ & $<0.001$ \\
\hline $\begin{array}{l}\text { R classification } \\
\text { R0 } \\
\text { RI } \\
\text { R2 }\end{array}$ & $\begin{array}{l}101(26.6 \%) \\
174(45.8 \%) \\
105(27.6 \%)\end{array}$ & & \\
\hline $\begin{array}{l}\text { Lauren classification } \\
\text { Intestinal } \\
\text { Diffuse } \\
\text { Mixed }\end{array}$ & $\begin{array}{l}142(37.4 \%) \\
220(57.9 \%) \\
18(4.7 \%)\end{array}$ & & \\
\hline $\begin{array}{l}\text { Histological grade } \\
\text { Well differentiated } \\
\text { Moderately differentiated } \\
\text { Poorly differentiated }\end{array}$ & $\begin{array}{l}66(17.4 \%) \\
197(51.8 \%) \\
117(30.8 \%)\end{array}$ & & \\
\hline $\begin{array}{l}\text { Location } \\
\text { Cardia } \\
\text { Non-cardia }\end{array}$ & $\begin{array}{l}|3|(34.5 \%) \\
249(65.5 \%)\end{array}$ & & \\
\hline $\begin{array}{l}\text { TNM } \\
\text { I+II } \\
\text { III+IV }\end{array}$ & $\begin{array}{l}129(33.9 \%) \\
25 \mid(66.1 \%)\end{array}$ & & \\
\hline $\begin{array}{l}\text { Tumor size } \\
\qquad 4 \mathrm{~cm} \\
\leq 4 \mathrm{~cm}\end{array}$ & $\begin{array}{l}248(65.3 \%) \\
132(34.7 \%)\end{array}$ & & \\
\hline $\begin{array}{l}\text { Histology } \\
\text { Adenocarcinoma } \\
\text { Not Adenocarcinoma }\end{array}$ & $\begin{array}{l}345(90.8 \%) \\
35(9.2 \%)\end{array}$ & & \\
\hline
\end{tabular}

Note: Bold values are statistically significant $(P<0.05)$.

Abbreviations: TNM, tumor node metastasis; R0, no cancer infiltration at the margin; RI, microscopic cancer infiltration; R2, macroscopic cancer infiltration.

that G19A polymorphism of LEP gene was related with lower risk for colon cancer. ${ }^{34}$ Partida-Perez et al suggested that this SNP was associated with colorectal cancer risk in

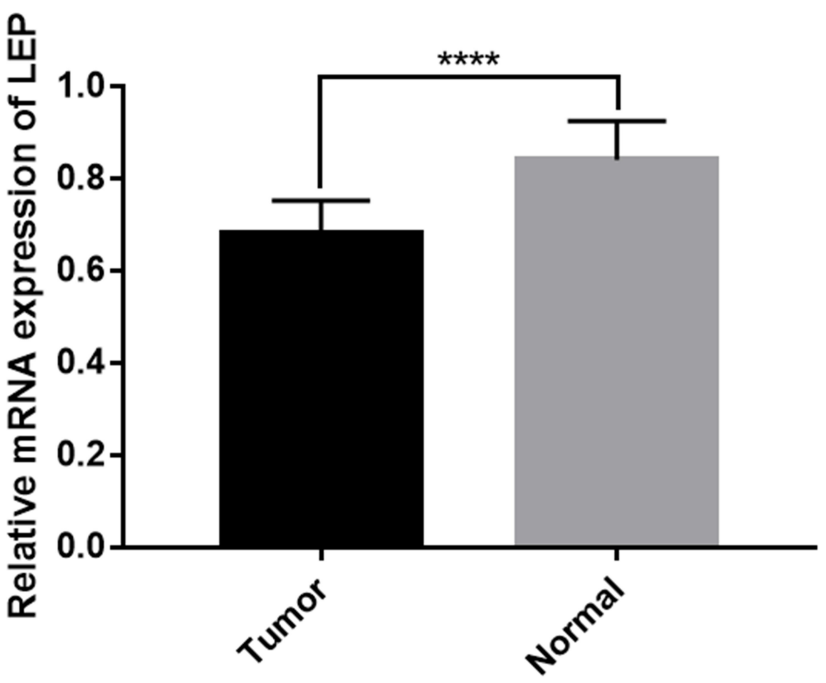

Figure 2 The LEP mRNA expression in gastric tissues and normal tissues. ***The LEP mRNA expression in gastric tissues was significantly lower than those in normal tissues $(P<0.00 \mathrm{I})$.

Abbreviation: LEP, leptin.

Mexican patients. $^{35}$ As for esophageal cancer, an Australian study showed LEP G19A polymorphism was inactive for esophageal carcinogenesis, ${ }^{36}$ which was in line with the findings of a Chinese study. ${ }^{37}$ However, another Chinese study indicated that LEP G19A polymorphism contributed to less risk for esophagogastric junction adenocarcinoma. ${ }^{38}$ As for prostate cancer, two studies obtained it was not heavily associated with $L E P$ G19A polymorphism. ${ }^{39,40}$ Next, several studies addressing the relationship between non-Hodgkin's lymphoma (NHL) risk and this polymorphism yielded conflicting findings. Willett et al suggested that G19A polymorphism was a protective factor for NHL; ${ }^{41}$ Skibola et al found this polymorphism increased the risk of NHL. ${ }^{42}$ Nevertheless, a Chinese study revealed that G19A polymorphism was not associated with susceptibility to NHL. ${ }^{43}$ In addition, Kim et $\mathrm{al}^{44}$ observed no connection between G19A polymorphism and breast cancer risk and Zhang et al showed this SNP was associated with the risk of hepatocellular carcinoma. ${ }^{45}$ Obviously, these studies obtained inconsistent results in different cancers regarding LEP G19A polymorphism. Some factors may account for paradoxical results. First, genetic heterogeneity existed in different cancers, and LEP G19A polymorphism may be a specific locus for some cancers. Second, clinical heterogeneity and third, the varying sample sizes may contribute to it. Fourth, different races are neglectable. Fifth, exposure factors and grade malignancy of cancers are different. 
Table 2 Genotype Frequencies of LEP GI9A Polymorphism in Cases and Controls

\begin{tabular}{|l|l|l|l|l|l|l|l|}
\hline Models & Genotype & Case (n, \%) & Control (n, \%) & OR (95\% CI) & $P$-value & $*$ OR (95\% Cl) & $* P$-value \\
\hline Co-dominant & GG & $245(64.6 \%)$ & $263(56.8 \%)$ & 1.00 & - & 1.00 \\
Heterozygote & GA & $120(31.7 \%)$ & $170(36.7 \%)$ & $0.76(0.57-1.01)$ & 0.062 & $0.75(0.56-1.01)$ & - \\
Homozygote & AA & $14(3.7 \%)$ & $30(6.5 \%)$ & $\mathbf{0 . 5 0 ( 0 . 2 6 - 0 . 9 7 )}$ & $\mathbf{0 . 0 4 0}$ & $\mathbf{0 . 4 9 ( 0 . 2 6 - 0 . 9 6 )}$ & $\mathbf{0 . 0 3 6}$ \\
\hline Dominant & GG & $245(64.6 \%)$ & $263(56.8 \%)$ & 1.00 & - & 1.00 & - \\
& AA+GA & $134(35.4 \%)$ & $200(43.2 \%)$ & $0.55(0.29-1.06)$ & 0.074 & $0.55(0.29-1.05)$ & 0.069 \\
\hline Recessive & GA+GG & $365(96.3 \%)$ & $433(93.5 \%)$ & 1.00 & - & 1.00 & - \\
& AA & $14(3.7 \%)$ & $30(6.5 \%)$ & $\mathbf{0 . 7 2 ( 0 . 5 4 - 0 . 9 5 )}$ & $\mathbf{0 . 0 2 I}$ & $\mathbf{0 . 7 2 ( 0 . 5 4 - 0 . 9 5 )}$ & $\mathbf{0 . 0 1 9}$ \\
\hline Allele & G & $610(80.5 \%)$ & $696(75.2 \%)$ & 1.00 & - & - & - \\
& A & $148(19.5 \%)$ & $230(24.8 \%)$ & $\mathbf{0 . 7 3 ( 0 . 5 8 - 0 . 9 3 )}$ & $\mathbf{0 . 0 0 9}$ & - \\
\hline
\end{tabular}

Notes: Bold values are statistically significant $(P<0.05)$; The genotyping was successful in 380 cases and 465 controls; *Adjust age and sex. Abbreviations: $\mathrm{OR}$, odds ratio; $\mathrm{Cl}$, confidence interval.

Table 3 Stratified Analyses Between LEP GI9A Polymorphism and the Risk of Gastric Cancer

\begin{tabular}{|c|c|c|c|c|c|c|c|}
\hline \multirow[t]{2}{*}{ Variable } & \multicolumn{3}{|c|}{ (Case/Control) } & \multirow{2}{*}{$\begin{array}{l}\text { GA vs GG } \\
\text { OR ( } 95 \% \mathrm{Cl}) ; P\end{array}$} & \multirow{2}{*}{$\begin{array}{l}\text { AA vs GG } \\
\text { OR ( } 95 \% \mathrm{Cl}) ; P\end{array}$} & \multirow{2}{*}{$\begin{array}{l}\text { AA vs GG+GA } \\
\text { OR ( } 95 \% \mathrm{Cl}) ; P\end{array}$} & \multirow{2}{*}{$\begin{array}{l}\text { AA+GA vs GG } \\
\text { OR ( } 95 \% \mathrm{Cl}) ; P\end{array}$} \\
\hline & GG & GA & AA & & & & \\
\hline \multicolumn{8}{|l|}{ Sex } \\
\hline Male & $127 / 134$ & $61 / 86$ & $8 / 21$ & $0.75(0.50-1.13) ; 0.036$ & $0.40(0.17-0.94) ; 0.036$ & $0.45(0.19-1.03) ; 0.059$ & $0.68(0.46-1.00) ; 0.052$ \\
\hline Female & $118 / 129$ & $59 / 84$ & $6 / 9$ & $0.77(0.51-1.16) ; 0.214$ & $0.73(0.25-2.11) ; 0.560$ & $0.80(0.28-2.30) ; 0.168$ & $0.76(0.51-1.14) ; 0.191$ \\
\hline \multicolumn{8}{|l|}{ Smoking } \\
\hline Yes & $120 / 127$ & $61 / 84$ & $10 / 17$ & $0.77(0.51-1.16) ; 0.212$ & $0.62(0.27-|.4|) ; 0.257$ & $0.69(0.3 \mathrm{I}-1.54) ; 0.359$ & $0.74(0.50-1.10) ; 0.140$ \\
\hline No & $125 / 136$ & $59 / 86$ & $4 / 13$ & $0.75(0.50-1.13) ; 0.163$ & $0.34(0.1 \mathrm{I}-1.05) ; 0.06 \mathrm{I}$ & $0.37(0.12-1.16) ; 0.088$ & $0.69(0.47-1.03) ; 0.071$ \\
\hline \multicolumn{8}{|l|}{ Alcohol } \\
\hline Yes & $130 / 135$ & $74 / 98$ & $9 / 13$ & $0.78(0.53-1.15) ; 0.217$ & $0.72(0.30-1.74) ; 0.464$ & $0.79(0.33-1.89) ; 0.597$ & $0.78(0.54-1.12) ; 0.183$ \\
\hline No & $115 / 128$ & $46 / 72$ & $5 / 17$ & $0.71(0.46-1.11) ; 0.135$ & $0.33(0.12-0.92) ; 0.033$ & $0.37(0.13-1.01) ; 0.053$ & $0.64(0.42-0.98) ; 0.039$ \\
\hline \multicolumn{8}{|l|}{ Age (years) } \\
\hline$<60$ & $149 / 169$ & $66 / 109$ & $5 / 17$ & $0.69(0.47-1.00) ; 0.051$ & $0.33(0.12-0.93) ; 0.035$ & $0.38(0.14-1.05) ; 0.061$ & $0.64(0.44-0.92) ; 0.016$ \\
\hline$\geq 60$ & $96 / 94$ & $54 / 61$ & $9 / 13$ & $0.88(0.55-1.38) ; 0.546$ & $0.68(0.28-1.66) ; 0.395$ & $0.72(0.30-1.72) ; 0.445$ & $0.83(0.54-1.30) ; 0.418$ \\
\hline \multicolumn{8}{|l|}{ H. pylori } \\
\hline Seropositive & $200 / 158$ & $99 / 100$ & $12 / 15$ & $0.78(0.55-1.11) ; 0.166$ & $0.63(0.29-1.39) ; 0.253$ & $0.69(0.32-1.50) ; 0.349$ & $0.76(0.55-1.07) ; 0.112$ \\
\hline Seronegative & $45 / 105$ & $21 / 70$ & $2 / 15$ & $0.70(0.38-1.28) ; 0.244$ & $0.31(0.07-1.42) ; 0.131$ & $0.35(0.08-1.59) ; 0.175$ & $0.63(0.35-1.13) ; 0.119$ \\
\hline
\end{tabular}

Note: Bold values are statistically significant $(P<0.05)$.

Abbreviations: OR, odds ratio; $\mathrm{Cl}$, confidence interval.

We firstly found that $L E P$ G19A polymorphism was connected to decreased risk for GC. Data suggested that AA genotype or A allele carriers decreased the risk of GC. However, another study observed that AA genotype was a risk factor for other cancers. ${ }^{45}$ We assumed that $L E P$ G19A polymorphism may play diverse roles in different cancers. To our knowledge, this is the first study to uncover the significant link between this SNP and GC susceptibility. Savino et al indicated LEP G19A polymorphism was linked with LEP down-expression. ${ }^{49}$ In addition, serum LEP downregulation may be a protective factor and predict good prognosis for breast cancer patients. ${ }^{50}$ Thereby, we assume that lower serum LEP levels related to genotypes of LEP G19A polymorphism may contribute to decreased risk for GC. However, further studies are needed to verify this assumption. Furthermore, subgroup analysis found that LEP G19A polymorphism was linked with a less risk for GC patients 
Table 4 The Associations Between LEP GI9A Polymorphism and Clinical Characteristics of Gastric Cancer

\begin{tabular}{|c|c|c|c|c|}
\hline \multirow[t]{2}{*}{ Characteristics } & \multicolumn{4}{|c|}{ Genotype Distributions } \\
\hline & GG & GA & AA & $\mathbf{G A}+\mathbf{A A}$ \\
\hline \multicolumn{5}{|l|}{ Histological grade } \\
\hline WD/PD & $41 / 76$ & $24 / 35$ & $1 / 6$ & $25 / 41$ \\
\hline OR (95\% Cl); $P$-value & 1.0 (reference) & I.27(0.67-2.42); 0.465 & $0.3 \mathrm{I}(0.036-2.65) ; 0.260$ & $1.13(0.61-2.11) ; 0.701$ \\
\hline \multicolumn{5}{|l|}{ Histological grade } \\
\hline MD/PD & $128 / 76$ & $61 / 35$ & $7 / 6$ & $80 / 129$ \\
\hline OR (95\% Cl); $P$-value & I.0 (reference) & $1.04(0.63-1.71) ; 0.894$ & $0.69(0.22-2.14) ; 0.521$ & $0.91(0.54-1.55) ; 0.729$ \\
\hline \multicolumn{5}{|l|}{$\mathrm{R}$ classification } \\
\hline $\mathrm{R} 1 / \mathrm{R} 2$ & $114 / 64$ & $55 / 36$ & $5 / 5$ & $60 / 41$ \\
\hline OR (95\% Cl); $P$-value & I.0 (reference) & $0.86(0.5 \mathrm{I}-\mathrm{I} .44) ; 0.563$ & $0.56(0.16-2.01) ; 0.370$ & $0.82(0.50-1.36) ; 0.442$ \\
\hline \multicolumn{5}{|l|}{$\mathrm{R}$ classification } \\
\hline R0/R2 & $67 / 64$ & $29 / 36$ & $4 / 5$ & $33 / 41$ \\
\hline OR (95\% Cl); $P$-value & 1.0 (reference) & $0.77(0.42-1.40) ; 0.389$ & $0.76(0.20-2.97) ; 0.697$ & $0.77(0.43-1.36) ; 0.368$ \\
\hline \multicolumn{5}{|l|}{ Location } \\
\hline Cardia/Non-cardia & $96 / 149$ & $34 / 86$ & $1 / 13$ & $35 / 99$ \\
\hline OR (95\% Cl); $P$-value & 1.0 (reference) & $0.61(0.38-0.98) ; 0.042$ & $0.12(0.02-0.93) ; 0.016$ & $0.55(0.35-0.87) ; 0.01 \mathrm{I}$ \\
\hline \multicolumn{5}{|l|}{ TNM } \\
\hline$|+| I / I I+\mid I V$ & $85 / 160$ & $40 / 80$ & $4 / 10$ & $44 / 90$ \\
\hline OR (95\% Cl); P-value & I.0 (reference) & $0.94(0.59-1.49) ; 0.800$ & $0.75(0.23-2.47) ; 0.639$ & $0.92(0.59-1.44) ; 0.715$ \\
\hline \multicolumn{5}{|l|}{ Tumor size } \\
\hline$>4 \mathrm{~cm} / \leq 4 \mathrm{~cm}$ & $161 / 84$ & $83 / 37$ & $4 / 10$ & $87 / 47$ \\
\hline OR (95\% Cl); P-value & I.0 (reference) & $1.17(0.73-1.87) ; 0.510$ & $0.21(0.06-0.69) ; 0.005$ & $0.97(0.62-1.50) ; 0.877$ \\
\hline \multicolumn{5}{|l|}{ Metastasis } \\
\hline MI/MO & $29 / 216$ & $14 / 106$ & $3 / 11$ & $17 / 117$ \\
\hline OR (95\% Cl); P-value & I.0 (reference) & $0.98(0.50-1.94) ; 0.962$ & $2.03(0.54-7.7 I) ; 0.289$ & I.08(0.57-2.05); 0.809 \\
\hline \multicolumn{5}{|l|}{ Histology } \\
\hline Adenocarcinoma/NOT & $230 / 15$ & $104 / 16$ & $10 / 4$ & $114 / 20$ \\
\hline OR (95\% Cl); P-value & I.0 (reference) & $0.42(0.20-0.89) ; 0.020$ & $0.16(0.05-0.58) ; 0.002$ & $0.37(0.18-0.75) ; 0.005$ \\
\hline
\end{tabular}

Note: Bold values are statistically significant $(P<0.05)$.

Abbreviations: $\mathrm{OR}$, odds ratio; $\mathrm{Cl}$, confidence interval; TNM, tumor node metastasis; PD, poorly differentiation; MD, moderately differentiation; WD, well differentiation; R0, no cancer infiltration at the margin; RI, microscopic cancer infiltration; R2, macroscopic cancer infiltration.

among the males, non-drinkers, and those aged $<60$ years, suggesting that those individuals are less susceptible to GC. On the contrary, the females, drinkers, and those aged $>60$ years may be prone to GC. From the view of GC management or prevention, those groups need to receive gastroscopy or other early examinations, which could help with early intervention on the occurrence of GC. Analyses concerning the relationship between LEP G19A polymorphism and clinical characteristics of GC patients found that this SNP was linked with the tumor size, cardia GC and adenocarcinoma. Furthermore, AA genotype was a protective factor for GC patients with smaller tumor size, non-cardia, and non-adenocarcinoma.
Limitations of this study existed. First, the relatively small sample size may yield false-positive results. Second, we did not investigate other SNPs of LEP gene. Third, gene-environment or gene-gene interaction was ignored. Fourth, the underlying mechanisms of the LEP G19A polymorphism in GC risk should be discovered. Fifth, we did collect the follow-up data of GC patients previously. Thus, we could not explore the correlation between GC prognosis and LEP G19A polymorphism at recent stage. Last, our findings should be validated in other populations in China and other races.

In sum, $L E P$ G19A polymorphism is linked with a lower risk of GC in Chinese individuals. Overall, our 
findings may be generally helpful for early screening of individuals at high-risk of GC in Chinese Han population. Further studies are needed, which will help to comprehensively elucidate the potential role of LEP G19A polymorphism in the pathogenesis of GC.

\section{Disclosure}

The authors report no conflicts of interest in this work.

\section{References}

1. Van Cutsem E, Sagaert X, Topal B, Haustermans K, Prenen H. Gastric cancer. Lancet. 2016;388(10060):2654-2664. doi:10.1016/ S0140-6736(16)30354-3

2. Chen W, Zheng R, Baade PD, et al. Cancer statistics in China, 2015. CA Cancer J Clin. 2016;66(2):115-132. doi:10.3322/caac.21338

3. Colquhoun A, Arnold M, Ferlay J, Goodman KJ, Forman D, Soerjomataram I. Global patterns of cardia and non-cardia gastric cancer incidence in 2012. Gut. 2015;64(12):1881-1888. doi:10.1136/ gutjnl-2014-308915

4. Ullah MF, Aatif M. The footprints of cancer development: cancer biomarkers. Cancer Treat Rev. 2009;35(3):193-200. doi:10.1016/j. ctrv.2008.10.004

5. Lunet N, Valbuena C, Vieira AL, et al. Fruit and vegetable consumption and gastric cancer by location and histological type: case-control and meta-analysis. Eur $J$ Cancer Prev. 2007;16(4):312-327. doi:10.1097/01.cej.0000236255.95769.22

6. Leja M, Grinberga-Derica I, Bilgilier C, Steininger C. Review: epidemiology of Helicobacter pylori infection. Helicobacter. 2019;24 (Suppl 1):e12635. doi:10.1111/hel.12635

7. Li WY, Han Y, Xu HM, et al. Smoking status and subsequent gastric cancer risk in men compared with women: a meta-analysis of prospective observational studies. BMC Cancer. 2019;19(1):377. doi:10. 1186/s12885-019-5601-9

8. Helgason H, Rafnar T, Olafsdottir HS, et al. Loss-of-function variants in ATM confer risk of gastric cancer. Nat Genet. 2015;47 (8):906-910. doi:10.1038/ng.3342

9. Shi Y, Hu Z, Wu C, et al. A genome-wide association study identifies new susceptibility loci for non-cardia gastric cancer at $3 \mathrm{q} 13.31$ and 5p13.1. Nat Genet. 2011;43(12):1215-1218. doi:10.1038/ng.978

10. Wang Z, Dai J, Hu N, et al. Identification of new susceptibility loci for gastric non-cardia adenocarcinoma: pooled results from two Chinese genome-wide association studies. Gut. 2017;66(4):58 1-587. doi:10.1136/gutjnl-2015-310612

11. Unger RH, Zhou YT, Orci L. Regulation of fatty acid homeostasis in cells: novel role of leptin. Proc Natl Acad Sci U S A. 1999;96 (5):2327-2332. doi:10.1073/pnas.96.5.2327

12. Li RJW, Zhang SY, Lam TKT. Interaction of glucose sensing and leptin action in the brain. Mol Metab. 2020;39:101011. doi:10.1016/j. molmet.2020.101011

13. Sanchez-Jimenez F, Perez-Perez A, de la Cruz-merino L, SanchezMargalet V. Obesity and breast cancer: role of leptin. Front Oncol. 2019;9:596. doi:10.3389/fonc.2019.00596

14. Ghadge AA, Khaire AA. Leptin as a predictive marker for metabolic syndrome. Cytokine. 2019;121:154735. doi:10.1016/j.cyto.2019.15 4735

15. Starling S. New therapeutic promise for leptin. Nat Rev Endocrinol. 2019;15(11):625. doi:10.1038/s41574-019-0265-8

16. Ray A, Cleary MP. The potential role of leptin in tumor invasion and metastasis. Cytokine Growth Factor Rev. 2017;38:80-97. doi:10.10 16/j.cytogfr.2017.11.002
17. Ghasemi A, Saeidi J, Azimi-Nejad M, Hashemy SI. Leptin-induced signaling pathways in cancer cell migration and invasion. Cell Oncol. 2019;42(3):243-260. doi:10.1007/s13402-019-00428-0

18. Olea-Flores M, Juarez-Cruz JC, Mendoza-Catalan MA, PadillaBenavides T, Navarro-Tito N. Signaling pathways induced by leptin during epithelial (-) mesenchymal transition in breast cancer. Int J Mol Sci. 2018;19:11. doi:10.3390/ijms19113493

19. Alshaker H, Krell J, Frampton AE, et al. Leptin induces upregulation of sphingosine kinase 1 in oestrogen receptor-negative breast cancer via Src family kinase-mediated, janus kinase 2-independent pathway. Breast Cancer Res. 2014;16(5):426. doi:10.1186/s13058-014-0426-6

20. Oba J, Wei W, Gershenwald JE, et al. Elevated serum leptin levels are associated with an increased risk of sentinel lymph node metastasis in cutaneous melanoma. Medicine. 2016;95(11):e3073. doi:10.1097/ MD.0000000000003073

21. Kato S, Abarzua-Catalan L, Trigo C, et al. Leptin stimulates migration and invasion and maintains cancer stem-like properties in ovarian cancer cells: an explanation for poor outcomes in obese women. Oncotarget. 2015;6(25):21100-21119. doi:10.18632/oncotarget.4228

22. Lee KN, Choi HS, Yang SY, et al. The role of leptin in gastric cancer: clinicopathologic features and molecular mechanisms. Biochem Biophys Res Commun. 2014;446(4):822-829. doi:10.1016/j.bbrc.2014.02.072

23. Dong Z, Fu S, Xu X, et al. Leptin-mediated regulation of ICAM-1 is $\mathrm{Rho} /$ ROCK dependent and enhances gastric cancer cell migration. $\mathrm{Br}$ J Cancer. 2014;110(7):1801-1810. doi:10.1038/bjc.2014.70

24. Wu N, Wang Y, Wang S, Chen Y, Yan J. Recombinant human leptin induces growth inhibition and apoptosis in human gastric cancer MGC-803 cells. Clin Exp Med. 2013;13(4):305-314. doi:10.1007/ s10238-012-0211-8

25. Inagaki-Ohara K. Gastric leptin and tumorigenesis: beyond obesity. Int J Mol Sci. 2019;20:11. doi:10.3390/ijms20112622

26. Isyraqiah F, M KK, Durairajanayagam D, Salim N, Singh H. Leptin induces the expression of tumorigenic genes in the gastric mucosa of male Sprague-Dawley rats. Exp Biol Med. 2018;1535370218813909. doi:10.1177/1535370218813909

27. Arita S, Ogawa T, Murakami Y, Kinoshita Y, Okazaki M, InagakiOhara K. Dietary fat-accelerating leptin signaling promotes protumorigenic gastric environment in mice. Nutrients. 2019;11:9. doi:10. 3390/nu11092127

28. Choi E, Byeon SJ, Kim SH, et al. Implication of leptin-signaling proteins and epstein-barr virus in gastric carcinomas. PLoS One. 2015;10(7):e0130839. doi:10.1371/journal.pone.0130839

29. Begenik H, Aslan M, Dulger AC, et al. Serum leptin levels in gastric cancer patients and the relationship with insulin resistance. Arch Med Sci. 2015;11(2):346-352. doi:10.5114/aoms.2015.50967

30. Tas F, Karabulut S, Erturk K, Duranyildiz D. Clinical significance of serum leptin level in patients with gastric cancer. Eur Cytokine Netw. 2018;29(2):52-58. doi:10.1684/ecn.2018.0408

31. Bain GH, Collie-Duguid E, Murray GI, et al. Tumour expression of leptin is associated with chemotherapy resistance and therapy-independent prognosis in gastro-oesophageal adenocarcinomas. Br J Cancer. 2014;110 (6):1525-1534. doi:10.1038/bjc.2014.45

32. Geng Y, Wang J, Wang R, et al. Leptin and HER-2 are associated with gastric cancer progression and prognosis of patients. Biomed Pharmacother. 2012;66(6):419-424. doi:10.1016/j.biopha.2012.03.002

33. Tsilidis KK, Helzlsouer KJ, Smith MW, et al. Association of common polymorphisms in IL10, and in other genes related to inflammatory response and obesity with colorectal cancer. Cancer Causes Control. 2009;20(9):1739-1751. doi:10.1007/s10552-009-9427-7

34. Slattery ML, Wolff RK, Herrick J, Caan BJ, Potter JD. Leptin and leptin receptor genotypes and colon cancer: gene-gene and gene-lifestyle interactions. Int J Cancer. 2008;122(7):1611-1617. doi:10.1002/ijc.23135

35. Partida-Perez M, de la Luz Ayala-madrigal M, Peregrina-Sandoval J, et al. Association of LEP and ADIPOQ common variants with colorectal cancer in Mexican patients. Cancer Biomark. 2010;7 (3):117-121. doi:10.3233/CBM-2010-0154 
36. Doecke JD, Zhao ZZ, Stark MS, et al. Single nucleotide polymorphisms in obesity-related genes and the risk of esophageal cancers. Cancer Epidemiol Biomarkers Prev. 2008;17(4):1007-1012. doi:10. 1158/1055-9965.EPI-08-0023

37. Qiu H, Lin X, Tang W, et al. Investigation of TCF7L2, LEP and LEPR polymorphisms with esophageal squamous cell carcinomas. Oncotarget. 2017;8(65):109107-109119. doi:10.18632/oncotarget.22 619

38. Yang J, Zhong Z, Tang W, Chen J. Leptin rs2167270 G > A (G19A) polymorphism may decrease the risk of cancer: A case-control study and meta-analysis involving 19989 subjects. J Cell Biochem. 2019. doi:10.1002/jcb. 28378

39. Moore SC, Leitzmann MF, Albanes D, et al. Adipokine genes and prostate cancer risk. Int J Cancer. 2009;124(4):869-876. doi:10.10 02/ijc. 24043

40. Wang MH, Helzlsouer KJ, Smith MW, et al. Association of IL10 and other immune response- and obesity-related genes with prostate cancer in CLUE II. Prostate. 2009;69(8):874-885. doi:10.1002/pros. 20933

41. Willett EV, Skibola CF, Adamson P, et al. Non-Hodgkin's lymphoma, obesity and energy homeostasis polymorphisms. $\mathrm{Br} J$ Cancer. 2005;93(7):811-816. doi:10.1038/sj.bjc.6602762

42. Skibola CF, Holly EA, Forrest MS, et al. Body mass index, leptin and leptin receptor polymorphisms, and non-Hodgkin lymphoma. Cancer Epidemiol Biomarkers Prev. 2004;13(5):779-786.

43. Zhang Y, Wang MY, He J, et al. Tumor necrosis factor-alpha induced protein 8 polymorphism and risk of non-Hodgkin's lymphoma in a Chinese population: a case-control study. PLoS One. 2012;7(5): e37846. doi:10.1371/journal.pone.0037846
44. Kim KZ, Shin A, Lee YS, Kim SY, Kim Y, Lee ES. Polymorphisms in adiposity-related genes are associated with age at menarche and menopause in breast cancer patients and healthy women. Hum Reprod. 2012;27(7):2193-2200. doi:10.1093/humrep/des147

45. Zhang S, Jiang J, Chen Z, et al. Investigation of LEP and LEPR polymorphisms with the risk of hepatocellular carcinoma: a case-control study in Eastern Chinese Han population. Onco Targets Ther. 2018;11:2083-2089. doi:10.2147/OTT.S153931

46. Zhuo ZJ, Zhang R, Zhang J, et al. Associations between IncRNA MEG3 polymorphisms and neuroblastoma risk in Chinese children. Aging. 2018;10(3):481-491. doi:10.18632/aging.101406

47. Wan Q, Zhang D, Zhou Q, et al. Association of CD44 gene rs187115 polymorphism with colorectal cancer risk and prognosis in Chinese Han population: a case-control study. Aging. 2019;11(21):9616-9625. doi:10.18632/aging.102408

48. Wang J, Zhuo Z, Chen M, et al. RAN/RANBP2 polymorphisms and neuroblastoma risk in Chinese children: a three-center case-control study. Aging. 2018;10(4):808-818. doi:10.18632/aging.101429

49. Savino F, Rossi L, Di Stasio L, Galliano I, Montanari P, Bergallo M. Mismatch amplification mutation assay real-time PCR analysis of the leptin gene G2548A and A19G polymorphisms and serum leptin in infancy: a preliminary investigation. Horm Res Paediatr. 2016;85 (5):318-324. doi:10.1159/000444484

50. Miyoshi Y, Funahashi T, Tanaka S, et al. High expression of leptin receptor mRNA in breast cancer tissue predicts poor prognosis for patients with high, but not low, serum leptin levels. Int J Cancer. 2006;118(6):1414-1419. doi:10.1002/ijc.21543
Pharmacogenomics and Personalized Medicine

\section{Publish your work in this journal}

Pharmacogenomics and Personalized Medicine is an international, peer-reviewed, open access journal characterizing the influence of genotype on pharmacology leading to the development of personalized treatment programs and individualized drug selection for improved safety, efficacy and sustainability. This journal is indexed on the American Chemical Society's Chemical Abstracts Service (CAS). The manuscript management system is completely online and includes a very quick and fair peer-review system, which is all easy to use. Visit http://www.dovepress.com/testimonials.php to read real quotes from published authors. 